\title{
Efficacy and safety of PDE5-Is and a-1 blockers for treating lower ureteric stones or LUTS: a meta-analysis of RCTs
}

Xifeng Sun ${ }^{1,2 \dagger}$, Wei Guan ${ }^{1 \dagger}$, Haoran Liu' ${ }^{1,2}$, Kun Tang ${ }^{1,2}$, Libin Yan ${ }^{1,2}$, Yangjun Zhang ${ }^{1,2}$, Jin Zeng ${ }^{1,2}$, Zhiqiang Chen ${ }^{1,2}$, Hua $\mathrm{Xu}^{1,2^{*}}$ and Zhangqun $\mathrm{Ye}^{1,2}$

\begin{abstract}
Background: Lower ureteric stones and lower urinary tract symptoms are common in urology.Drug treatment is one of standard therapy,but the efficacy was controversial.Thus we aimed to investigate the efficacy and safety of monotherapy or combination therapy of adrenoceptor1 blockers and phosphodiesterase 5 inhibitors for treatment.

Methods: Randomized controlled trials up to November 2016 were retrieved from PubMed, the Cochrane Library, Web of Science and Embase. A total of 17 studies were included. We analyzed data through random or fixed effect models. The heterogeneity between studies was assessed by the $I^{2}$ test statistic.

Results: As for lower ureter stones, our analysis demonstrated tadalafil had a significantly lower incidence of abnormal ejaculation than adrenoceptor 1 blockers $(2.3195 \% \mathrm{Cl} 0.22$ to $0.84, P=0.01)$, while combination therapy had a higher expulsion rate $(2.4995 \% \mathrm{Cl} 1.44$ to $4.29, P=0.001)$ and shorter expulsion time $(-1.9895 \% \mathrm{Cl}-3.08$ to 0.88 , $P=0.0004$ ) than tamsulosin. As for lower urinary tract symptoms, our analysis indicated adrenoceptor 1 blockers was more effective than phosphodiesterase 5 inhibitors on decreasing International Prostate Symptom Score (1.96 95\% Cl 0.03 to 3.89, $P=0.05)$ and Post-Void Residual $(9.4195 \% \mathrm{Cl} 1.40$ to $14.41, P=0.02)$ and phosphodiesterase5 inhibitors showed a greater effect than adrenoceptor1 blockers on improving Erectile Dysfunction $(2.2395 \% \mathrm{Cl} 1.24$ to 3.22 , $P<0.0001)$.Combination therapy had a significantly better effect on International Prostate Symptom Score (1.47 $95 \% \mathrm{Cl} 1.25$ to $1.69, P<0.0001)$, Maximum flow rate $(0.8795 \% \mathrm{Cl} 0.71$ to $1.04, P<0.0001)$, Post-Void Residual $(10.7495 \% \mathrm{Cl}$ 3.53to 17.96, $P=0.004)$ and Quality of life $(0.5995 \% \mathrm{Cl} 0.22$ to $0.97, P=0.002)$ but was associated with higher incidences of adverse events $(3.4095 \% \mathrm{Cl} 1.82$ to6.36, $P=0.0001)$ than adrenoceptor1 blockers. Combination therapy had a significantly better effect on International Prostate Symptom Score $(4.1995 \% \mathrm{Cl} 3.34$ to $5.04, P<0.0001)$, Maximum flow rate $(1.86$ 95\%Cl 1.32to 2.39, $P<0.0001)$, Post-Void Residual $(22.5895 \% \mathrm{Cl}$ 9.13to36.04, $P=0.001)$ and Quality of life $(0.6895 \% \mathrm{Cl} 0.37 \mathrm{to} 1.00, P<0.0001)$ without higher incidences of adverse events than PDE5-Is.

Conclusions: In conclusion, this meta-analysis suggested combination therapy had a best efficacy of therapy for lower ureteric stones or lower urinary tract symptoms correlated with benign prostatic hyperplasia than monotherapy. Adrenoceptor1 blockers was more effective than phosphodiesterase5 inhibitors on International Prostate Symptom Score and Post-Void Residual. Both monotherapy and combination therapy were safe.
\end{abstract}

Keywords: Adrenergic alpha-1 receptor antagonists, Phosphodiesterase 5 inhibitors, Ureteral calculi, Lower urinary tract symptoms, Prostatic hyperplasia

\footnotetext{
* Correspondence: xuhuawhu@163.com

${ }^{\dagger}$ Equal contributors

${ }^{1}$ Department of Urology, Tongji Hospital, Tongji Medical College, Huazhong

University of Science and Technology, Wuhan 430030, China

${ }^{2}$ Institute of Urology of Hubei Province, Wuhan 430030, China
}

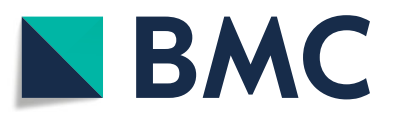

(c) The Author(s). 2018 Open Access This article is distributed under the terms of the Creative Commons Attribution 4.0 International License (http://creativecommons.org/licenses/by/4.0/), which permits unrestricted use, distribution, and

reproduction in any medium, provided you give appropriate credit to the original author(s) and the source, provide a link to the Creative Commons license, and indicate if changes were made. The Creative Commons Public Domain Dedication waiver (http://creativecommons.org/publicdomain/zero/1.0/) applies to the data made available in this article, unless otherwise stated. 


\section{Background}

Benign prostatic hyperplasia (BPH) is characterized by nonmalignant hyperplasia of prostatic tissue and is caused by proliferation of smooth muscle (SM) and epithelial cell in the transition zone of prostate.BPH is common in aging men and could result in bothersome lower urinary tract symptoms correlated with $\mathrm{BPH}$ (LUTS/BPH) which decrease Quality of life (QoL) by interrupting sleep and daily activities $[1,2]$. In the US, approximately $75 \%$ of males from 60 to 69 years old and $83 \%$ of men aged 70 years or older are estimated to have got LUTS/BPH, and the annual direct medical cost due to management is more than $\$ 1.1$ billion [3].

Each year, about $0.1 \%$ of the adult population of the US are admitted to hospital for treating urinary stones, leading to direct medical costs of more than $\$ 2$ billion per year [4]. Stone incidence varies by race, ethnicity, geographic region and is higher in mountainous areas and deserts located in the southern US and Central European areas [5]. Nowadays, kidney stones are most prevailing from 20 to 40 years old and the incidence of men are 2 to 3 times higher as compared with women, which may due to less calcium and more citrate excreted by women. About $22 \%$ of all urinary calculus locate in the ureter, of which about $68 \%$ are found in the distal ureter [6].

In the past 20 years, various therapy methods for LUTS/BPH and lower ureteric stones were developed, which included observation, drug treatment and surgical procedures [7-10]. At present, drug treatment has become standard therapy and is widely recommended by clinical guidelines for LUTS/BPH and lower ureteric stones after series randomized controlled trials (RCTs) revealing the obvious effect of adrenoceptor blockers(ABs) [8]. $\alpha$-1adrenergic receptors play significant roles in the contraction of SMs of the urinary tract and mainly centralize in the distal ureter, and relaxation of these SMs by blocking the receptors will improve LUTS/ $\mathrm{BPH}$ and cause ureter dilatation contributing to stone expulsion [11].

Recently, the phosphodiesterase5 inhibitors (PDE5-Is) such as tadalafil, have shown up which could relax the SMs of ureter and prostate by working on nitric oxide cyclic-guanine monophosphate (NO/cGMP) signaling pathway [12-14]. Because of this character, tadalafil was approved by FDA in treating LUTS/BPH, erectile dysfunction (ED) and pulmonary arterial hypertension [15] and PDE5-Is were acknowledged in the guidelines published by the Japanese Urological Association (JUA) and the European Association of Urology (EAU). There is Level 1 evidence supporting the efficacy of PDE5-Is for treating LUTS/BPH [16]. By combining drugs acting through different mechanisms, better relaxation of SMs could be achieved [17]. Like ABs, PDE5-Is have an onset of action that occurs within weeks. However, the two classes of drugs are associated with adverse events (AEs) such as headache, dizziness and hypotension leading to the relatively limited clinical application.

Nowadays, a few meta-analyses had compared the effect of PDE5-Is with ABs in the therapy of LUTS/BPH but meta-analyses about lower ureteric stones were rare. In 2012, Gacci et al. [18] performed a meta-analysis of PDE5-Is plus $A B s$ verse $A B s$ for treating LUTS/BPH. They declared that PDE5-Is might be a treatment option with great promise for patients with LUTS/BPH. Then several clinical trials analyzed the effect of PDE5-Is for LUTS/BPH vs ABs. In 2015, XH Wang et al. [19] conducted an meta-analysis to summarize the comparative effect and safety of monotherapy and combination therapy of PDE5-Is and ABs for LUTS/BPH, in which they suggested that PDE5-Is used alone was effective except for Post-Void Residual (PVR) than ABs and was more effective than $A B s$ on increase of International Index Of Erectile Function (IIEF) score while combination therapy had the best effect. Moreover, either monotherapy or combination therapy was safe. However, the literature searches weren't extensive enough in the two studies.

Recently, researchers focused on investigating the comparative effect and safety of monotherapy and combined use of PDE5-Is and ABs for treating LUTS/BPH and lower ureteric stones. However, the conclusions were still very controversial. Thus, our study aimed to comprehensively compare efficiency and safety of monotherapy with combination therapy of PDE5-Is and ABs for treating LUTS/BPH and lower ureteric stones based on existing RCTs.

\section{Methods}

All methods for this systematic review and meta-analysis are outlined in a prospectively registered protocol available online [20] (PROSPERO identifier CRD42017059295) , and reporting follows Preferred Reporting Items for Systematic Reviews and Meta-Analysis (PRISMA) guidelines.

\section{Search strategy}

According to the PRISMA statement [21], we performed an extensive search of a database of PubMed, the Cochrane Library, Web of Science and Embase up to November 2016. The search terms included the following keywords: ("lower urinary tract symptom" OR "LUTS" OR "benign prostatic hyperplasia" OR "BPH" OR "ureter stone" OR "ureteric stone") AND ("a-adrenoceptor antagonist" OR "a-adrenoceptor inhibitor" OR " $\alpha$ blocker" OR "alfuzosin" OR "doxazosin" OR "tamsulosin" OR "silodosin" OR "terazosin") AND ("phosphodiesterase type 5 inhibitor" OR "sildenafil" OR "tadalafil" OR "mirodenafil" OR "avanafil" OR "udenafil" OR "vardenafil" OR "lodenafil"). Furthermore, the references of selected articles 
and the abstracts presented at related conferences were also checked by hand to identify additional potential studies. The languages were limited to English.

\section{Inclusion and exclusion criteria}

The inclusion criteria for the studies were as follows: (1) human studies; (2) reporting original research;(3) enrolling patients of LUTS/BPH or lower ureteric stone; (4) reporting evaluation indexes of LUTS/BPH such as IPSS, Qmax, PVR, QoL, IIEF before and after treatment; (5) reporting evaluation indexes of stones such as expulsion rate, expulsion time. Additionally, reviews, superficial abstracts, studies with a sample size $<10$ were excluded.

\section{Selection of studies}

Two authors (XFS and WG) respectively screened the title, abstract and results, keywords and conclusion of every single study to identify included articles. Any discrepancies were resolved by discussing together. Full texts were screened to further evaluate whether the article had met the inclusion criteria.

\section{Data extraction}

Two authors (XFS and WG) respectively extracted the required data from the included articles through using a designed tabulation based on the Inclusion criteria and a third author verified the data. Data of different aspects were classified into the corresponding column. Based on the Cochrane Handbook, missing or vague information was imputed and was required from the authors of original articles or other relevant articles when necessary.

\section{Quality assessment}

Two investigators independently assessed the quality levels of the included studies according to the Jadad score, which is based on the following aspects: randomized allocation sequence, allocation concealment, blinding and quitting. Studies with scores of 4 points or higher were considered to be of high quality.

\section{Statistical analysis}

All analyses were conducted applying Cochrane Collaboration review manager software (RevMan5.3). The pooled effects were calculated as weighted mean difference (WMD) for continuous variable and odds ratio (OR) for dichotomy variable, as well as $95 \%$ confidence intervals (Cls). We chose two-sided in all test and $P<0$. 05 were considered statistical significance. The heterogeneity was determined by the Cochrane's Q-statistic test [22], and the inconsistency was quantified with the $\mathrm{I}^{2}$ statistic. When $\mathrm{I}^{2}>50 \%$ or $\mathrm{P}_{\mathrm{Q}} \leq 0.1$, which suggested substantial heterogeneity, the random-effects model (DerSimonian-Laird method) was applied [23]; otherwise, the fixed-effects model (Mantel-Haenszel method) was applied [24]. Sensitivity analyses were conducted by sequentially excluding each study to validate the reliability of the results and analyse the heterogeneity. Evaluation of safety was conducted via comparing the AEs, and the indexes could be calculated when at least 2 studies contained relevant data.

\section{Results}

\section{Search results}

Figure 1 displayed the study selection process. Of 127 retrieved articles in initial search, 17 RCTs finally met full inclusion criteria via full-text evaluation from 33 potentially eligible articles for this systematic review and meta-analysis.

\section{Study characteristics and quality assessment}

Tables 1 and 2 list the characteristics of the included studies in the meta-analysis. Regarding the lower ureteric stones, 5 studies [6,13, 25-27] including a total of 861 patients were available. Regarding the LUTS/ BPH, 12 studies [28-39] including a total of 1052 patients were available. As for bias, we gave positive appraise for all the selected studies. Additionally, 13 $[6,13,25-30,33,35,37,38,40]$ included studies were of high quality and $4[31,32,34,36]$ were of low quality according to the Jadad scores [41].

\section{Quantitative synthesis \\ $P D E 5$-is versus $A B$ s for lower ureteric stones}

As displayed in Fig. 2 and Additional file 1: Table S1, baseline characteristics, treatment outcomes and AEs were not statistically different except for the abnormal ejaculation between the two groups. There was a trend that $\mathrm{ABs}$ had a lower incidence of headache, dizziness and backache. Combining the results of included studies, PDE5-Is was comparable on the efficacy of lower ureter stones passage and had a significantly lower rate of abnormal ejaculation (2.31[1.19 to 4.50]; $P=0.01)$ than ABs. Sensitivity analysis was conducted by excluding each of the 4 studies.When excluding the study of Kumar (2015') et al. [13] the pooled odds ratio (OR) of expulsion rate and expulsion time was 0.37 (95\%CI: $0.21-0.65, P=0.0005$ ) and 1.90 (95\%CI: $0.98-2.82, P<0.0001$ ), respectively, demonstrating tadalafil might have better expulsion effect and shorter expulsion time than tamsulosin.

\section{Tadalafil plus tamsulosin versus tamsulosin for lower ureteric stones}

As displayed in Fig. 3 and Additional file 1: Table S1, the pooled WMD for expulsion time, no. of hospital visits, no. of colic episodes and analgesic use was $-1.98(95 \% \mathrm{CI}$ : -3 . 08-0.88, $P=0.0004),-0.71$ (95\%CI: $-0.92-0.50, \quad P<0$. 0001), -1.15 (95\%CI: $-1.34-0.96, P<0.0001)$ and -1.03 (95\%CI: $-1.23-0.83, \mathrm{P}<0.0001$ ), respectively and the pooled OR for expulsion rate and Improvement in ED was 2,49 
Table 1 Characteristics of the included studies of lower ureteric stones in meta-analysis

\begin{tabular}{|c|c|c|c|c|c|c|c|c|c|c|}
\hline \multirow[t]{2}{*}{ Author } & \multirow[t]{2}{*}{ Year } & \multirow[t]{2}{*}{ Country } & \multicolumn{2}{|c|}{$\begin{array}{l}\text { Characteristics } \\
\text { of participants }\end{array}$} & \multirow[t]{2}{*}{ Design } & \multirow[t]{2}{*}{ Intervention } & \multirow[t]{2}{*}{ No. } & \multirow[t]{2}{*}{$\begin{array}{l}\text { Study } \\
\text { interval }\end{array}$} & \multirow[t]{2}{*}{ Comparable index } & \multirow[t]{2}{*}{$\begin{array}{l}\text { Jadac } \\
\text { score }\end{array}$} \\
\hline & & & location & size & & & & & & \\
\hline Kumar & 2015 & India & $\begin{array}{l}\text { distal } \\
\text { ureteric } \\
\text { stones }\end{array}$ & $\begin{array}{l}5-10 \\
\mathrm{~mm}\end{array}$ & $\mathrm{RCT}$ & $\begin{array}{l}\text { tamsulosin } 0.4 \mathrm{mg} \text { qd } \\
\text { tadalafil } 10 \mathrm{mg} \text { qd } \\
\text { silodosin } 8 \mathrm{mg} \text { qd }\end{array}$ & $\begin{array}{l}90 \\
90 \\
90\end{array}$ & 4 weeks & $\begin{array}{l}\text { age,gender,stone } \\
\text { size,expulsion } \\
\text { rate,expultion } \\
\text { time,analgesic use,AEs }\end{array}$ & 6 \\
\hline KC & 2016 & Nepal & $\begin{array}{l}\text { distal } \\
\text { ureteric } \\
\text { stones }\end{array}$ & $\begin{array}{l}5-10 \\
\mathrm{~mm}\end{array}$ & $\mathrm{RCT}$ & $\begin{array}{l}\text { tamsulosin } 0.4 \mathrm{mg} \text { qd } \\
\text { tadalafil } 10 \mathrm{mg} \mathrm{qd}\end{array}$ & $\begin{array}{l}41 \\
44\end{array}$ & 2 weeks & $\begin{array}{l}\text { age,gender,stone size, } \\
\text { expulsion rate, expulsion } \\
\text { time,analgesic use,AEs }\end{array}$ & 4 \\
\hline Puvvada & 2016 & India & $\begin{array}{l}\text { distal } \\
\text { ureteric } \\
\text { stones }\end{array}$ & $\begin{array}{l}5-10 \\
\mathrm{~mm}\end{array}$ & $\mathrm{RCT}$ & $\begin{array}{l}\text { tadalafil } 10 \mathrm{mg} \mathrm{qd} \\
\text { tamsulosin } 0.4 \mathrm{mg} \text { qd }\end{array}$ & $\begin{array}{l}100 \\
100\end{array}$ & 4 weeks & $\begin{array}{l}\text { age, gender, stone size, } \\
\text { expulsion rate, expulsion } \\
\text { time, analgesic use, AEs }\end{array}$ & 6 \\
\hline \multirow[t]{2}{*}{ Kumar } & \multirow[t]{2}{*}{2014} & \multirow[t]{2}{*}{ India } & \multirow{2}{*}{$\begin{array}{l}\text { distal } \\
\text { ureteric } \\
\text { stones }\end{array}$} & \multirow[t]{2}{*}{ 5-10 mm } & \multirow[t]{2}{*}{$\mathrm{RCT}$} & $\begin{array}{l}\text { tamsulosin } 0.4 \mathrm{mg} \\
\mathrm{qd}+\text { tadalafil } 10 \mathrm{mg} \mathrm{qd}\end{array}$ & 31 & \multirow[t]{2}{*}{6 weeks } & \multirow{2}{*}{$\begin{array}{l}\text { age,gender,stone size, } \\
\text { expulsion rate, expulsion } \\
\text { time,analgesic use, AEs }\end{array}$} & \multirow[t]{2}{*}{4} \\
\hline & & & & & & tamsulosin $0.4 \mathrm{mg} \mathrm{qd}$ & 31 & & & \\
\hline \multirow[t]{2}{*}{ Jayant } & \multirow[t]{2}{*}{2014} & \multirow[t]{2}{*}{ India } & \multirow{2}{*}{$\begin{array}{l}\text { distal } \\
\text { ureteric } \\
\text { stones }\end{array}$} & \multirow[t]{2}{*}{$\begin{array}{l}5-10 \\
\mathrm{~mm}\end{array}$} & \multirow[t]{2}{*}{$\mathrm{RCT}$} & $\begin{array}{l}\text { tamsulosin } 0.4 \mathrm{mg} \mathrm{qd}+ \\
\text { tadalafil } 10 \mathrm{mg} \mathrm{qd}\end{array}$ & 122 & \multirow[t]{2}{*}{4 weeks } & \multirow{2}{*}{$\begin{array}{l}\text { age, gender,stone size, } \\
\text { expulsion rate, } \\
\text { expulsion time, analgesic } \\
\text { use, AEs }\end{array}$} & \multirow[t]{2}{*}{5} \\
\hline & & & & & & tamsulosin $0.4 \mathrm{mg} \mathrm{qd}$ & 122 & & & \\
\hline
\end{tabular}

/ not available, $A E s$ adverse events, $R C T$ randomized controlled trial

(95\%CI: 1.44-4.29, $P=0.001)$ and 22.92 (95\%CI: 3.02-173. $82, P=0.002)$, respectively. The resultsindicated the combination therapy of tadalafil and tamsulosin was more effective on treating ED and lower ureteric stones without higher rate of AEs than tamsulosin. Sensitivity analysis was not performed because only 2 studies were included.

\section{PDE5-is versus $A B$ s for LUTS/BPH}

As displayed in Fig. 4 and Additional file 1: Table S1, ABs was significantly more effective than PDE5-Is on decreasing PVR (-9.41 [-17.41 to -1.40$] ; P=0.02)$ and
IPSS ( 1.96 [ -3.89 to -0.03$] ; P=0.05)$, while PDE5-Is showed greater effect than $\mathrm{ABs}$ on increasing IIEF score (2.23 [1.24 to 3.22]; $P<0.0001)$. Sensitivity analysis was conducted, and when ruling out the study of Kim et al. [29] the pooled WMD of change of Qmax was - 0.78 (95\%CI:-1.41-0.15,P =0.02) which meant ABs might have a better effect in increasing Qmax. The pooled WMD of the change of PVR was - 8.58 (95\%CI: -19.34$2.19, P=0.12$ ) after excluding the low-quality study of Kaplan et al. [32] which indicated there might have no statistical significance on decreasing PVR. When ruling

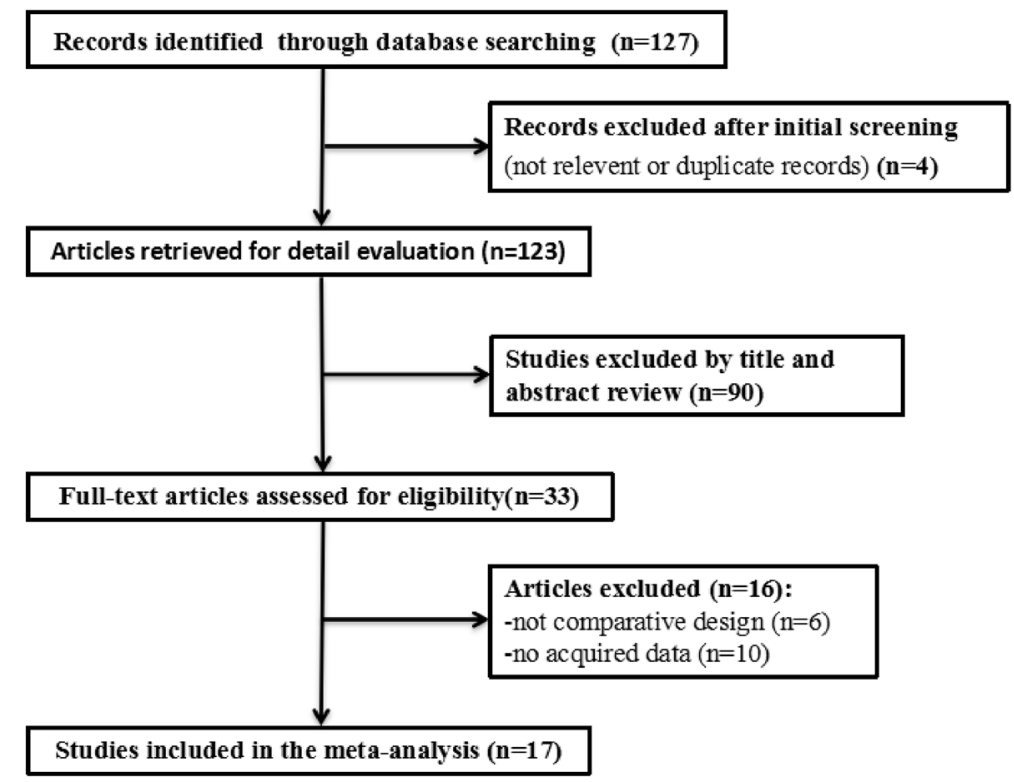

Fig. 1 Flow chart of study selection 
out the three low-quality studies of Kaplan et al. [32],Singh et al. [31] and Liguori et al. [36] the pooled WMD of change of IPSS was - 1.24 (95\%CI:-3.11-0. $79, P=0.19)$ which meant $A B s$ might not have a better effect in decreasing IPSS.

\section{PDE5-is plus $A B$ s versus $A B s$ for $L U T S / B P H$}

As displayed in Fig. 5 and Additional file 1: Table S1, the pooled WMD for change of IPSS, QoL, IIEF score, Qmax and PVR was 1.47 (95\%CI: $1.25-1.69, P<0.0001$ ), 0.59 (95\%CI: $0.22-0.97, P=0.002$ ), 2.83 (95\%CI: $2.08-3$. 58, $P<0.0001$ ), 0.87 (95\%CI: $0.71-1.04, P<0.0001)$ and 10.74 (95\%CI: $3.53-17.96, P=0.004$ ), respectively, indicating PDE5-Is plus $\mathrm{ABs}$ had better effect on improving LUTS/BPH than ABs alone. PDE5-Is plus ABs had higher incidences of AEs (3.69 [2.38 to 5 . 74]; $P<0.0001)$, headache (4.87 [2.28 to 5.74]; $P<0$. 0001) and dyspepsia (6.67 [1.46 to 30.55]; $P=0.01$ ) than ABs alone. Sensitivity analysis was conducted and there was no significant change.
PDE5-Is plus ABs versusPDE5-Is for LUTS/BPH

As displayed in Fig. 6 and Additional file 1: Table S1, the pooled WMD for change of IPSS, QoL, Qmax and PVR was 4.19 (95\%CI: 3.34-5.04, P < 0.0001), 0.68 (95\%CI: 0 . 37-1.00, $\mathrm{P}<0.0001$ ), 1.86 (95\%CI: 1.32-2.39, $P<0.0001$ ) and 22.58 (95\% CI: 9.13-36.04, $P=0.001$ ), respectively, indicating PDE5-Is plus ABs had a significantly better effect on improving LUTS/BPH and ED without increased incidences of AEs than PDE5-Is alone. Sensitivity analysis was conducted and there was no significant change.

\section{Discussion}

This is the first systematic review and metaanalysiscomparing the efficacy and safety of monotherapy and combination therapy of PDE5-Is and ABs for treating lower ureteric stones. Meanwhile, it is an update in LUTS/BPH. A few meta-analyses had analyzed the effect of PDE5-Is for treating LUTS/BPH when compared with ABs or placebo [42-44]. In 2015, XH Wang et al. worked out several different conclusions comparing with our analysis in LUTS/BPH which could mainly attribute

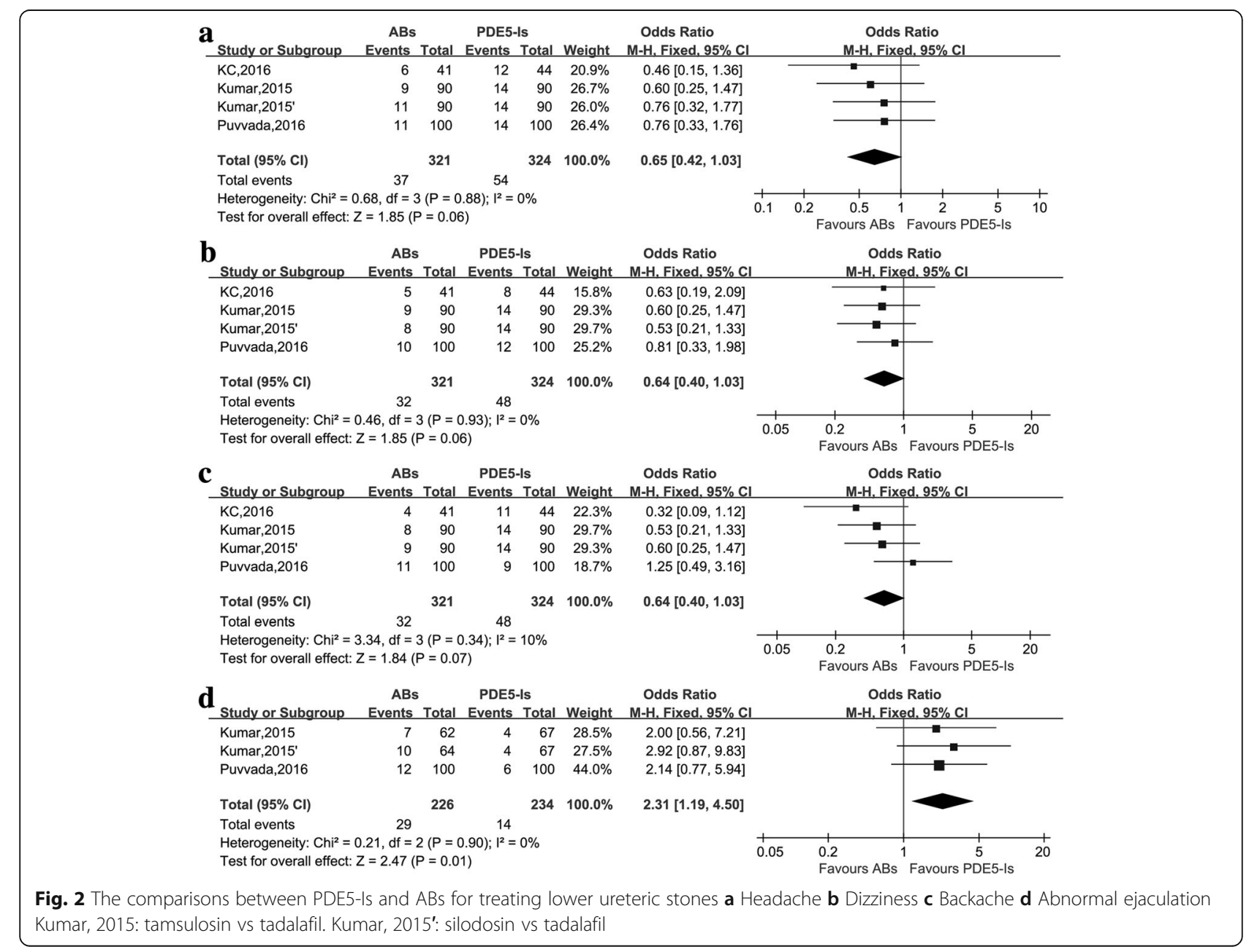


Table 2 Characteristics of the included studies of LUTS/BPH in meta-analysis

\begin{tabular}{|c|c|c|c|c|c|c|c|c|c|c|c|c|c|}
\hline \multirow[t]{2}{*}{ Author } & \multirow[t]{2}{*}{ Year } & \multirow[t]{2}{*}{ Country } & \multicolumn{5}{|c|}{ Characteristics of participants } & \multirow[t]{2}{*}{ Design } & \multirow[t]{2}{*}{ Intervention } & \multirow[t]{2}{*}{ No. } & \multirow{2}{*}{$\begin{array}{l}\text { Study } \\
\text { interval }\end{array}$} & \multirow{2}{*}{$\begin{array}{l}\text { Comparable } \\
\text { index }\end{array}$} & \multirow{2}{*}{$\begin{array}{l}\text { Jadad } \\
\text { score }\end{array}$} \\
\hline & & & $\overline{\text { Age }}$ & $\begin{array}{l}\text { Cause of } \\
\text { LUTS }\end{array}$ & IPSS & $E D$ & Sick time & & & & & & \\
\hline Abolyosr & 2013 & Egypt & $\geq 45$ & $\mathrm{BPH}$ & $\geq 7$ & Yes & $\geq 3$ months & RCT & $\begin{array}{l}\text { Doxazosin } 2 \mathrm{mg} \text { qd } \\
\text { Sildenafil } 50 \mathrm{mg} \text { qd } \\
\text { Combination }\end{array}$ & $\begin{array}{l}50 \\
50 \\
50\end{array}$ & 4 months & $\begin{array}{l}\text { IPSS, PVR, } \\
\text { Qmax, IIEF, } \\
\text { QoL }\end{array}$ & 4 \\
\hline Kaplan & 2007 & USA & $\begin{array}{l}50- \\
76\end{array}$ & $\mathrm{BPH}$ & 17.4(mean) & Yes & / & $\mathrm{RCT}$ & $\begin{array}{l}\text { Alfuzosin } 10 \text { mg qd } \\
\text { Sildenafil } 25 \text { mg qd } \\
\text { Combination }\end{array}$ & $\begin{array}{l}20 \\
21 \\
21\end{array}$ & 12 weeks & $\begin{array}{l}\text { IPSS, Qmax, } \\
\text { Nocturia, } \\
\text { PVR, IIEF, } \\
\text { AEs }\end{array}$ & 3 \\
\hline \multirow[t]{2}{*}{$\mathrm{KIM}$} & \multirow[t]{2}{*}{2011} & \multirow[t]{2}{*}{ Korea } & \multirow[t]{2}{*}{$\geq 45$} & \multirow[t]{2}{*}{$\mathrm{BPH}$} & \multirow[t]{2}{*}{$\geq 13$} & \multirow[t]{2}{*}{ / } & \multirow[t]{2}{*}{$\geq 6$ months } & \multirow[t]{2}{*}{$\mathrm{RCT}$} & Tadalafil $5 \mathrm{mg}$ qd & \multirow{2}{*}{$\begin{array}{l}51 \\
49\end{array}$} & \multirow[t]{2}{*}{12 weeks } & \multirow{2}{*}{$\begin{array}{l}\text { IPSS, QoL, } \\
\text { Nocturia, } \\
\text { Qmax, PVR, } \\
\text { AEs }\end{array}$} & \multirow[t]{2}{*}{5} \\
\hline & & & & & & & & & Tamsulosin $0.2 \mathrm{mg} \mathrm{qd}$ & & & & \\
\hline Singh & 2014 & India & $\geq 45$ & $\mathrm{BPH}$ & $>8$ & / & $\geq 6$ months & $\mathrm{RCT}$ & $\begin{array}{l}\text { Tamsulosin } 0.4 \mathrm{mg} \text { qd } \\
\text { Tadalafil } 10 \mathrm{mg} \text { qd } \\
\text { Combination }\end{array}$ & $\begin{array}{l}45 \\
44 \\
44\end{array}$ & 3 months & $\begin{array}{l}\text { IPSS, Qmax, } \\
\text { PVR, QoL, } \\
\text { IIEF, AEs }\end{array}$ & 3 \\
\hline \multirow[t]{2}{*}{ Tuncel } & \multirow[t]{2}{*}{2010} & \multirow[t]{2}{*}{ Turkey } & \multirow[t]{2}{*}{$\begin{array}{l}47- \\
77\end{array}$} & \multirow[t]{2}{*}{$\mathrm{BPH}$} & \multirow[t]{2}{*}{$>12$} & \multirow[t]{2}{*}{ Yes } & \multirow[t]{2}{*}{$\geq 6$ months } & $\mathrm{RCT}$ & $\begin{array}{l}\text { Sildenafil } 25 \text { mg qd } \\
\text { 4d/week }\end{array}$ & 20 & 8 weeks & $\begin{array}{l}\text { IPSS, Qmax, } \\
\text { PVR, QoL, }\end{array}$ & 4 \\
\hline & & & & & & & & & $\begin{array}{l}\text { Tamsulosin } 0.4 \mathrm{mg} \text { qd } \\
\text { Combination }\end{array}$ & $\begin{array}{l}20 \\
20\end{array}$ & & & \\
\hline Bechara & 2008 & Argentina & $\begin{array}{l}> \\
50\end{array}$ & $\mathrm{BPH}$ & $>12$ & / & $\geq 6$ months & RCCT & $\begin{array}{l}\text { Tamsulosin } 0.4 \mathrm{mg} \text { qd } \\
+ \text { tadalafil } 20 \mathrm{mg} \text { qd }\end{array}$ & 27 & 45 days & $\begin{array}{l}\text { IPSS, Qmax, } \\
\text { PVR, QoL, }\end{array}$ & 5 \\
\hline & & & & & & & & & $\begin{array}{l}\text { Tamsulosin } 0.4 \mathrm{mg} \mathrm{qd} \\
+ \text { placebo }\end{array}$ & 27 & & & \\
\hline Liguori & 2009 & Italy & $\begin{array}{l}50- \\
75\end{array}$ & $\mathrm{BPH}$ & $>8$ & Yes & $\geq 6$ months & MRCT & $\begin{array}{l}\text { Alfuzosin } 10 \text { mg qd } \\
\text { Tadalafil } 20 \text { mg qd } \\
\text { Combination }\end{array}$ & $\begin{array}{l}18 \\
19 \\
21\end{array}$ & 12 weeks & $\begin{array}{l}\text { IPSS, Qmax, } \\
\text { PVR, QoL, } \\
\text { IIEF, AEs }\end{array}$ & 3 \\
\hline $\mathrm{Ng}$ & 2009 & China & $\begin{array}{l}50- \\
80\end{array}$ & $\mathrm{BPH}$ & / & Yes & / & RCCT & $\begin{array}{l}\text { Doxazosin } 0.4-0.8 \mathrm{mg} \\
\mathrm{qd}+\text { vardenafil } 10 \mathrm{mg} \text { qd }\end{array}$ & 37 & 2 days & AEs & 6 \\
\hline & & & & & & & & & $\begin{array}{l}\text { Doxazosin } 0.4-0.8 \mathrm{mg} \\
\mathrm{qd}+\text { placebo }\end{array}$ & 37 & & & \\
\hline Regadas & 2013 & Brazil & $\begin{array}{l}> \\
45\end{array}$ & $\mathrm{BPH}$ & $>14$ & / & $\geq 6$ months & $\mathrm{RCT}$ & $\begin{array}{l}\text { Tamsulosin } 0.4 \mathrm{mg} \text { qd } \\
+ \text { tadalafil } 5 \mathrm{mg} \mathrm{qd}\end{array}$ & 20 & 30 days & $\begin{array}{l}\text { IPSS, Qmax, } \\
\text { QoL, AES }\end{array}$ & 5 \\
\hline & & & & & & & & & Tamsulosin 0.4 mg qd & 20 & & & \\
\hline Gacci & 2012 & Italy & $\begin{array}{l}40- \\
80\end{array}$ & $\mathrm{BPH}$ & $\geq 12$ & $\begin{array}{l}\text { Yes/ } \\
\text { No }\end{array}$ & / & $\mathrm{RCT}$ & $\begin{array}{l}\text { Vardenafil } 10 \mathrm{mg} \mathrm{qd}+ \\
\text { tamsulosin } 0.4 \mathrm{mg} \text { qd }\end{array}$ & 30 & 2 weeks & $\begin{array}{l}\text { IPSS, Qmax, } \\
\text { PVR, QoL, }\end{array}$ & 5 \\
\hline & & & & & & & & & $\begin{array}{l}\text { Tamsulosin } 0.4 \mathrm{mg} \mathrm{qd} \\
+ \text { Placebo }\end{array}$ & 30 & & & \\
\hline Kumar & 2014 & India & $>$ & $\mathrm{BPH}$ & $\geq 8$ & / & / & $\mathrm{RCT}$ & Alfuzosin $10 \mathrm{mg}$ qd & 25 & 12 weeks & IPSS, IIEF, & 5 \\
\hline & & & 50 & & & & & & Tadalafil 10 mg qd & 25 & & $\begin{array}{l}\text { Qmax, PVR, } \\
\text { Ool }\end{array}$ & \\
\hline & & & & & & & & & Combination & 25 & & & \\
\hline Jin & 2011 & China & $\begin{array}{l}50- \\
75\end{array}$ & $\mathrm{BPH}$ & $\geq 10$ & Yes & / & MRCT & $\begin{array}{l}\text { Doxazosin } 4 \text { mg qd + } \\
\text { sildenafil } 25-100 \text { mg } \\
\text { on demand }\end{array}$ & 168 & 6 months & $\begin{array}{l}\text { IPSS, QoL, } \\
\text { IIEF, AES }\end{array}$ & 3 \\
\hline & & & & & & & & & $\begin{array}{l}\text { Sildenafil 25-100 mg } \\
\text { on demand }\end{array}$ & 82 & & & \\
\hline
\end{tabular}

LUTS lower urinary tract symptom, BPH benign prostatic hyperplasia, ED erectile dysfunction, Qmax maximum flow rate, IPSS international prostase Symptom score, PVR postvoid residual urine, QoL quality of life, IIEF international index of erectile function, / not available, $A E s$ adverse events, $R C T$ randomized controlled trial, MRCT multicenter randomized controlled trial, $R C C T$ randomized controlled crossover trial

to the incomplete literature search. However, we made an integrated and high-quality literature search and most of the included studies were high-quality RCTs.

As for LUTS/BPH, our pooled results suggested that ABs had a significantly better effect than PDE5-Is on the reduction of IPSS and PVR without significant difference of Qmax and QoL. Meanwhile, PDE5-Is had a statistically significant better effect than ABs on improving IIEF score. This suggested PDE5-Is could exert different therapeutic effect by relieving the obstruction of prostate 


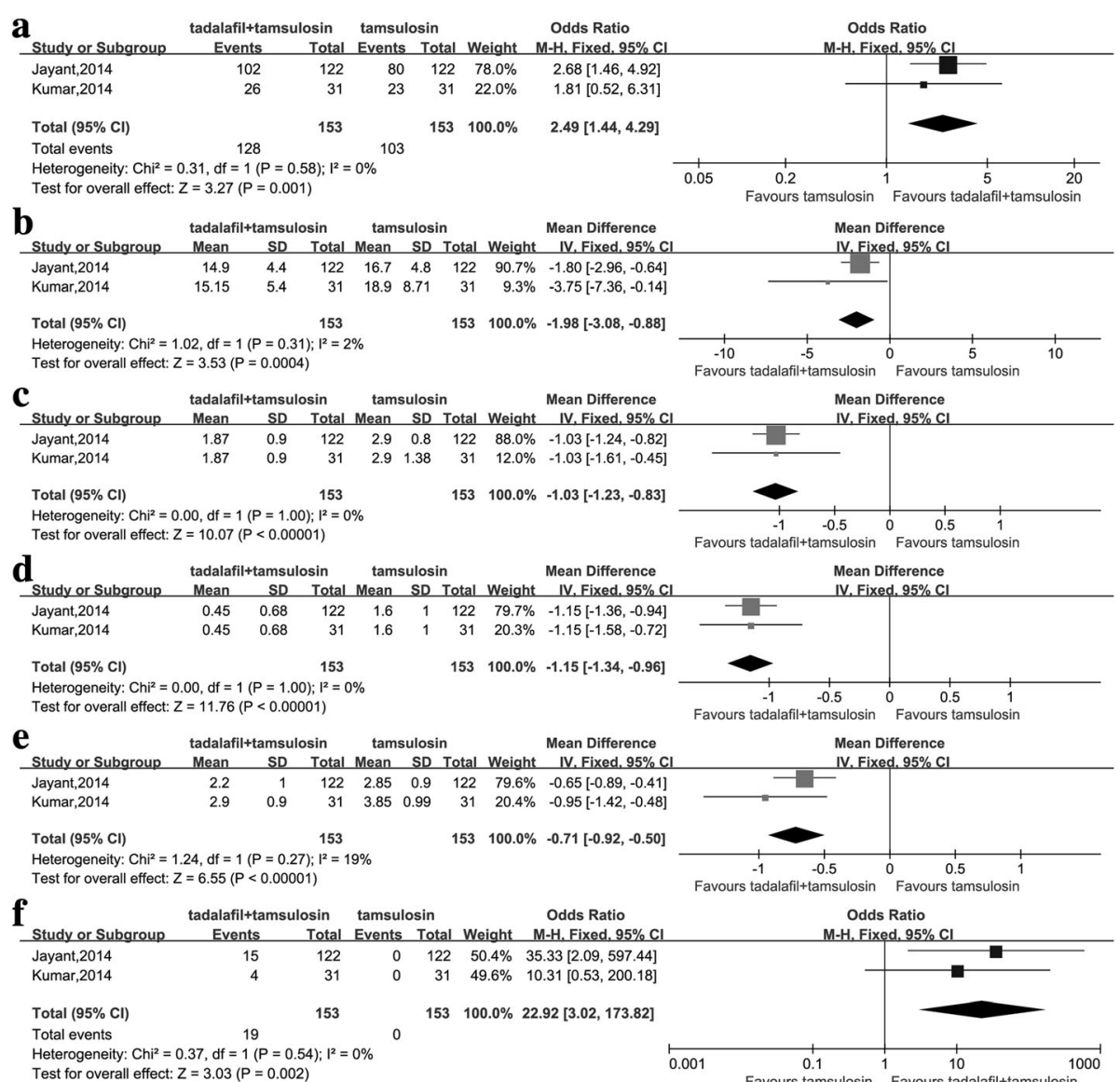

Fig. 3 The comparisons between combination therapy and tamsulosin monotherapy for treating lower ureteric stones $\mathbf{a}$ Expulsion rate $\mathbf{b}$ Expulsion time c Analgesic use $\mathbf{d}$ No. of colic episodes e No. of hospital visits $\mathbf{f} /$ mprovement in ED

and relaxing the bladder SMs [45]. The relaxation of PDE5-Is in the detrusor muscle could withstand the relaxation of prostate and bladder neck, which lessen the effect of urodynamics, especially PVR and IPSS [46].We also found that combination therapy had the best effect on reducing IPSS, PVR, and on increasing Qmax and QoL compared with either of monotherapy, while the combination therapy was significantly more effective on improving IIEF score compared with ABs. The results might demonstrate the therapy of tadalafil daily don't have a negative impact on bladder contractility and outlet condition [47]. No significant difference on increasing IIEF score between combination therapy and monotherapy of PDE5-Is was found, which demonstrated that ABs had little power to improve ED. Significant heterogeneity was detected among treatment outcomes of all the three comparisons for treating LUTS/BPH, which might due to various methods and doses, quality, and duration of intervention.

It is important that our meta-analysis revealed that the combination therapy for treating LUTS/BPH showed better effect than either monotherapy on reducing IPSS and PVR and increasing QoL and Qmax. The best effect may result from the synergistic function of $\mathrm{NO}$ mediated relaxation effect by PDE5-Is, and reduction of the sympathetic tone mediated by $\alpha$-adrenergic receptors blocking by $\mathrm{ABs}$ of the identical SMs in the bladder neck and prostate [32]. Also, our results corroborated the efficacy of combination therapy for patients suffered from LUTS and ED. In the comparison of PDE5-Is with ABs for LUTS/BPH, we found that $A B s$ had significantly better effect on increasing Qmax than PDE5-Is after removing the study of Kim et al. and the pooled WMD for change of PVR turned to be non-significant after removing the study of Kaplan et al., which could be explained by large sample size and low quality, respectively. When ruling out all the three low-quality studies of Kaplan et al. [32], Singh et al. [31] and Liguori et al. [36], the pooled WMD of change of IPSS turned to be non-significant, which meant ABs might not have a better effect in decreasing IPSS.

Variations of the outcomes could also be explained by different baseline characteristics such as age, BMI, and initial risk factors for LUTS/BPH. 


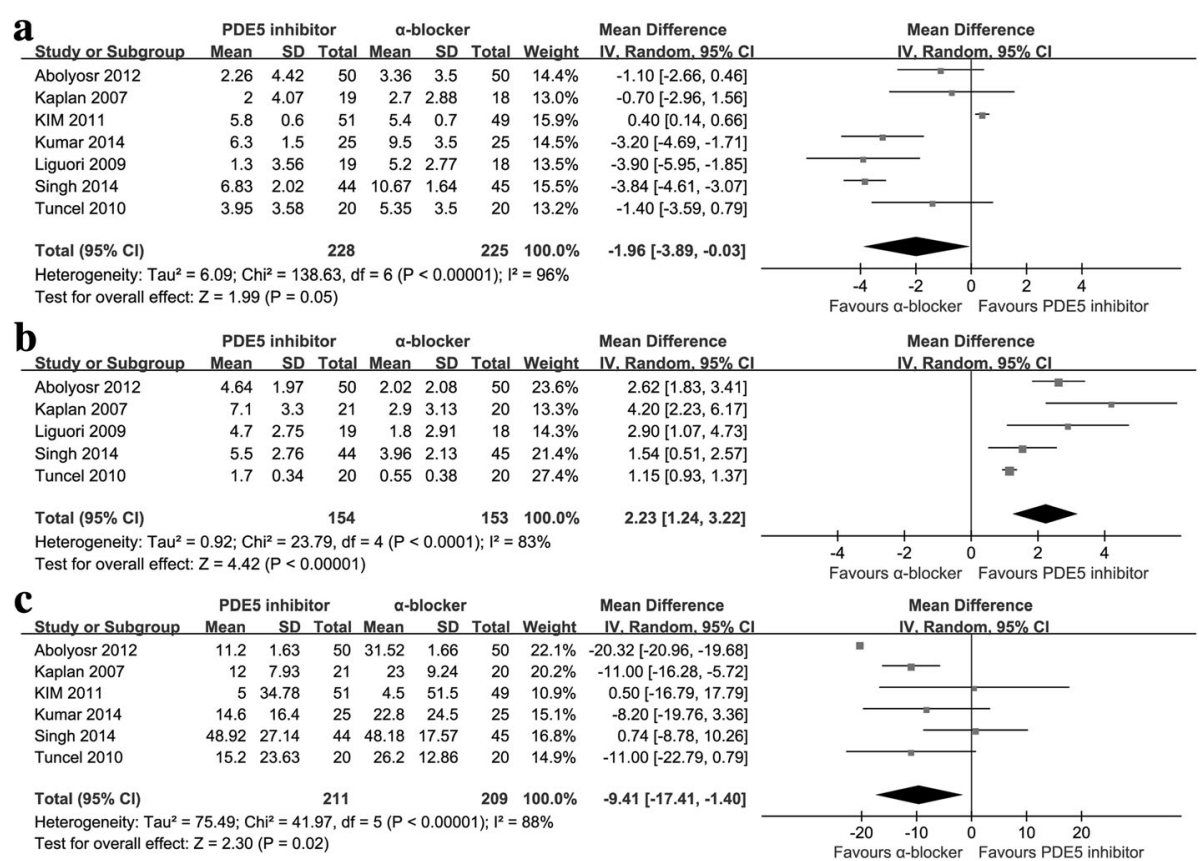

Fig. 4 The comparisons between PDE5-Is and ABs for treating LUTS/BPH a Change of IPSS $\mathbf{b}$ Change of IIEF score $\mathbf{c}$ Change of PVR

It is clear that substantial work has been conducted to verify the relationship between ED and LUTS/BPH. Both of them are highly prevailing in older men and are closely linked [48], independently of cardiovascular problems, as confirmed by numerous epidemiology researches [10, 49-51]. At present, the connection between ED and LUTS/BPH is supported by four primary mechanisms in the penis and prostate as followed: (1)the rhokinase activation/endothelin pathway; (2)the metabolic syndrome hypothesis and autonomic hyperactivity; (3)the physiopathologic consequences of pelvic atherosclerosis; (4)changes in the NO/cGMP pathway [52]. PDE5 isoenzymes play a role in the metabolisms and exist in the human bladder, prostate and urethra. Moreover, there is increasing evidence that PDE5-Is may be effective for LUTS/BPH [53-55].

As for AEs, our pooled results suggested that PDE5-Is plus $A B s$ had a higher incidence of total AEs, headache and dyspepsia than $A B s$ without significant difference in other two comparisons of LUTS/BPH, which suggested the addition of PDE5-Is to ABs could increase risks of the AEs in treating LUTS to some extent. It is wise to be prudent in comparing the AEs of similar medicines even though tiny differences in the mechanisms. In the study of XH Wang et al., the occurrence rate of AEs for the combination treatment was only numerically greater than either of monotherapy, and this might due to the inadequate size of the sample. Based on the present RCTs, most related AEs of cases were slight or moderate and only a few patients discontinued due to AEs.
Therefore, the overall safety profile of the two classes of drugs was good.

As for lower ureteric stones, the pooled results of this study indicated that tadalafil had better expulsion effect and shorter expulsion time than tamsulosin, and tadalafil had a lower incidence of abnormal ejaculation compared with ABs, which could be explained that tadalafil played a better role in relaxing SMs of posterior urethra than that of anterior urethra and bladder neck. This result reminds us that prescribing $\mathrm{ABs}$ for patients with lower ureteric stones and ejaculatory dysfunction should be prudent, and tadalafil may be a good substitute. And tadalafil plus $\mathrm{ABs}$ had significantly better improvement on IIEF score, higher expulsion rate, shorter expulsion time, less analgesic use and fewer hospital visits than ABs monotherapy without increased AEs. Our results demonstrated that tadalafil had an impressive improvement on expelling lower ureteric stones when combined with $\mathrm{ABs}$ and the combination therapy was safe for patients. Significant heterogeneity was observed among treatment outcomes of comparing $\mathrm{ABs}$ with PDE5-Is, which might due to various methods and duration of intervention.

At present, two convincing mechanisms of tadalafil in expelling lower ureteric stones are as followed: (1) slightto-moderate relaxation of SMs; (2) extension of local blood vessels which increases blood perfusion [56-58]. Increased NO/cGMP concentration could relax the SMs in the prostate, urethra and bladder,and increased blood perfusion may relieve intraprostatic inflammation, ureter 


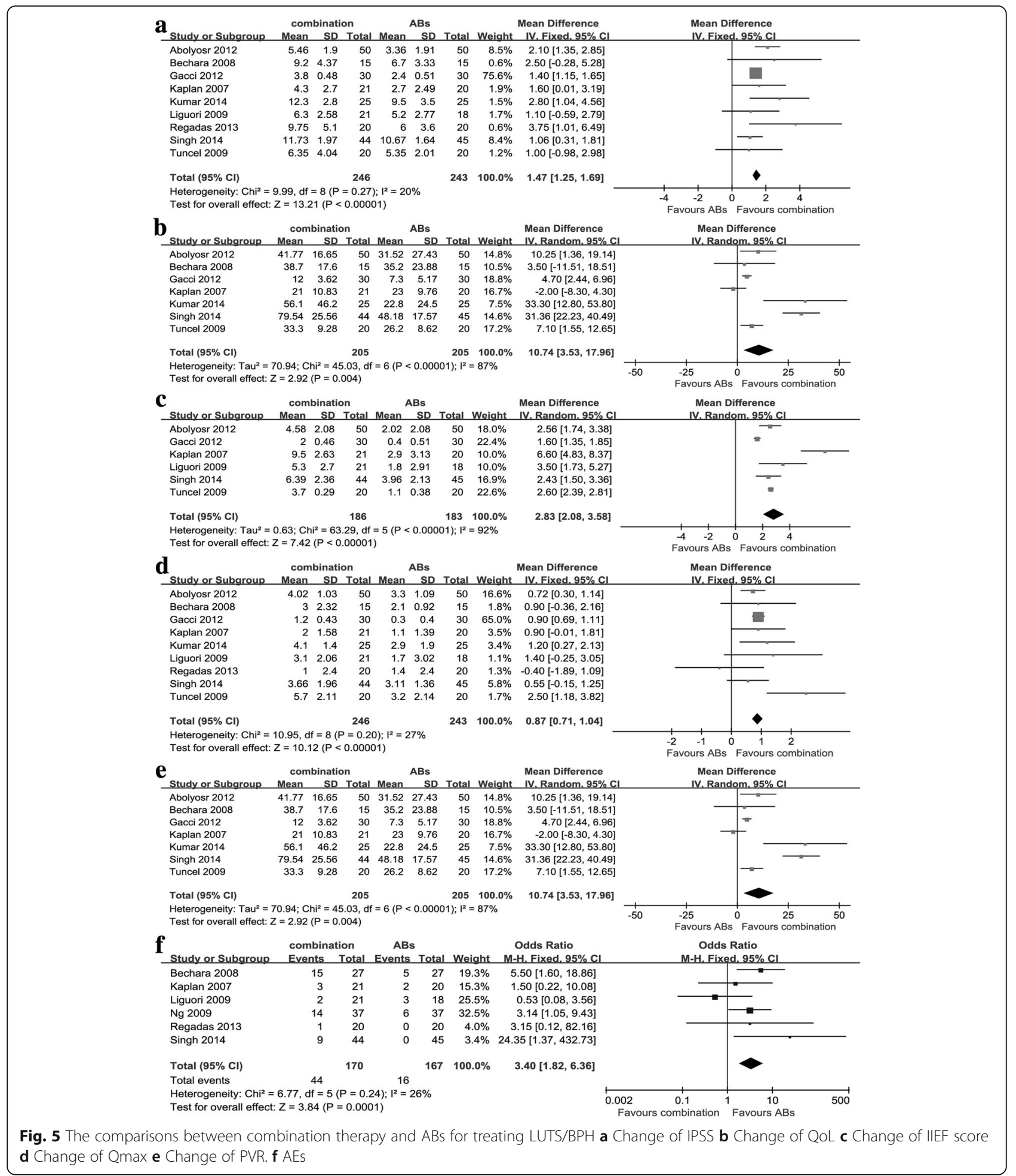

spasms and mucosal edema, which may contribute to the expulsion of lower ureteric stones.

Unfortunately, the important issue of PDE5-Is, the daily cost, has not been investigated, and none of the included RCTs had a performed cost analysis. The cost of drug therapy is directly related to the long-term efficacy and safety profile, and the QoL of men treated with PDE5-Is alone or in combination with other drugs in continuous administration.

Nevertheless, there were several main limitations when analyzing and interpreting results in our present systematic review and meta-analysis. The major limitation was 


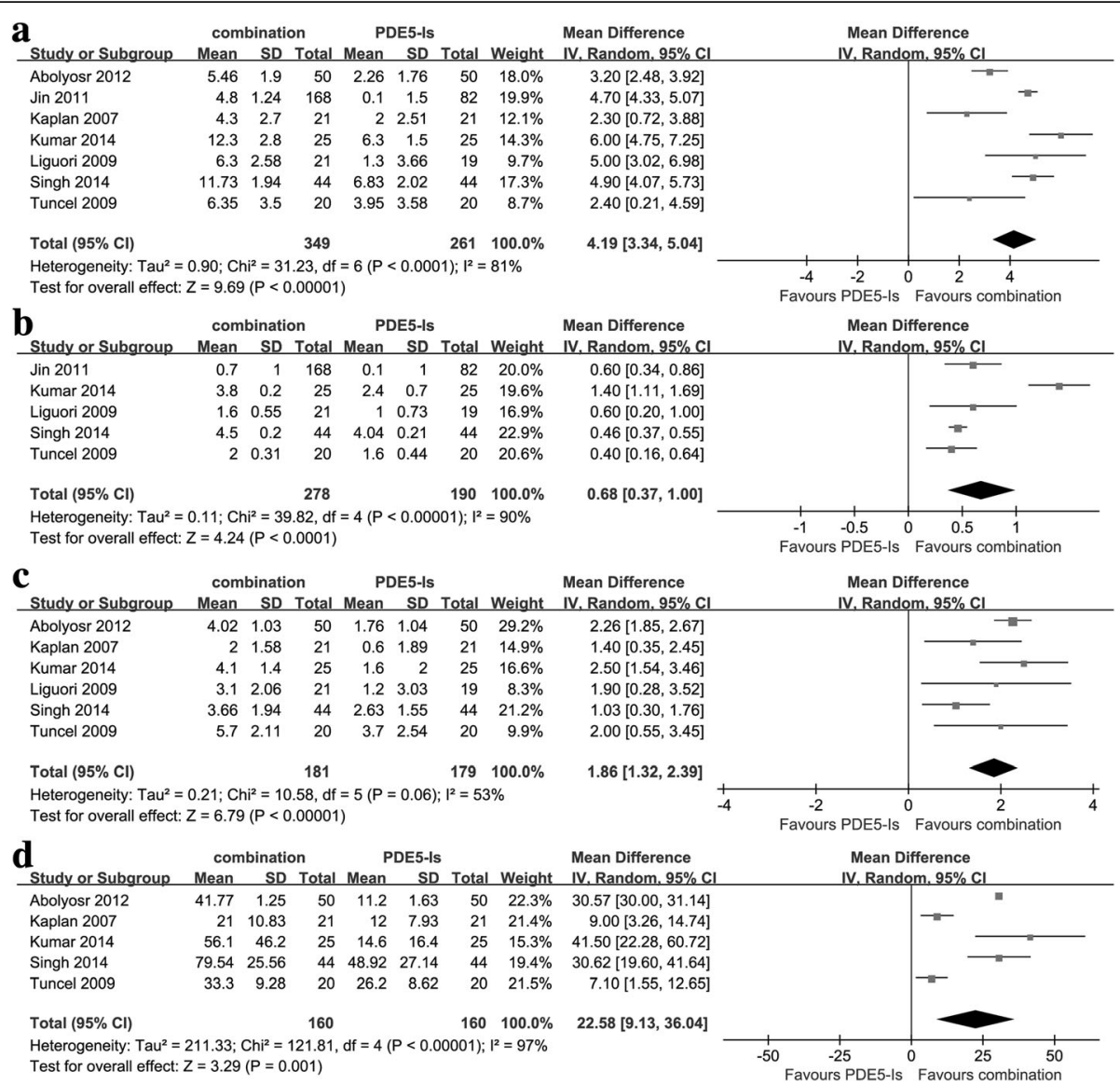

Fig. 6 The comparisons between combination therapy and PDE5-Is for treating LUTS/BPH a Change of IPSS b Change of QoL c Change of Qmax d Change of PVR

the quantity and various qualities and it was difficult to perform subgroup analysis to evaluate the heterogeneity among the included studies. In Table 1, we evaluated the quality by Jadad score and 4 RCTs had got 3 points which meant low-quality, which may limit the quality grade of evidence although other studies were evaluated as high-quality. Secondly, short duration and small populations also had a huge impact on the overall results. Thirdly, uncontrollable lifestyle modifications might influence the results. In our study, there were significant changes when removing some certain studies, which indicated there existed instability in our consequences, which might due to small sample size, inconsistent quality and the heterogeneity of the included original RCTs.

In the further, well-designed, prospective, multicenter randomized control studies with data of cost analysis, longer duration and larger sample size, and fundamental researches surveying mechanisms of PDE5-Is treating LUTS/BPH and lower ureteric stones, are required to help us better demonstrate the advantages as well as drawbacks of combination drug therapies. Clinical trials on the basis of the highest quality standard and method should be encouraged to ensure that the results have statistical significance and clinical relevance at the same time.

\section{Conclusion}

In conclusion, our study indicated that combination therapy of PDE5-Is and ABs had the best effect on improving LUTS/BPH or expulsing lower ureteric stones. As for monotherapy therapy, ABs had a better effect on improving LUTS/BPH and PDE5-Is were more effective on treating ED. Monotherapy use of PDE5-Is was effective on improving LUTS/BPH except for less reduction of PVR and IPSS as compared with ABs. Monotherapy of tadalafil had a better effect on expulsing lower ureteric stones than tamsulosin and had a lower incidence of abnormal ejaculation than ABs. What's more, monotherapy or combination therapy was safe and tolerant. Our results affirmed the therapeutic effect and safety of PDE5-Is and ABs, and provided evidences for drug treatment and update of guideline of LUTS/BPH or lower ureteric stones. 


\section{Additional file}

Additional file 1: Table S1. Outcomes including baseline

characteristics, treatment outcomes and adverse effects of this study. ABs a-1 blockers, PDE5-Is phosphodiesterase 5 inhibitors, BPH benign prostatic hyperplasia, LUTS lower urinary tract symptoms, ED erectile dysfunction, OR odds ratio, WMD weighted mean difference, Cl confidence interval, IPSS International Prostate Symptom Score, PVR postvoid residual urine, Qmax maximum flow rate, IIEF International Index of Erectile Function, QoL quality of life, AEs adverse effects. (DOCX $27 \mathrm{~kb}$ )

\section{Abbreviations}

ABs: Adrenoceptor1 blockers; AEs: Adverse events; $\mathrm{BPH}$ : Benign prostatic hyperplasia; CGMP: Cyclic-guanine monophosphate; Cl: Confidence interval; EAU: European association of urology; ED: Erectile dysfunction; IIEF: International index of erectile function; IPSS: International prostate symptom score; JUA: Japanese urological association; LUTS: Lower urinary tract symptoms; NO: Nitric oxide; OR: Odds ratio; PDE5-

Is: phosphodiesterase5 inhibitors; PVR: Post-void residual; Qmax: Maximum flow rate; QOL: Quality of life; RCT: Randomized controlled trials; SM: Smooth muscle; WMD: Weighted mean difference

\section{Funding}

This work was supported by the National Natural Science Foundation of China (81470935, 81370805, 81670645), the Chenguang Program of Wuhan Science and Technology Bureau (2015070404010199, 2015071704021644), and the National High Technology Research and Development Program 863 (2014AA020607).

No interferences occurred in carrying out the research project and in writing the manuscript that is the sole responsibility of the authors.

\section{Availability of data and materials}

All the data supporting our findings is contained in the manuscript.

\section{Authors' contributions}

XFS, WG and KT: Study conception and design, data collection and management; HRL, LBY, JZ and YJZ: data collection and analysis, preparation of figures and tables; XFS, WG, KT, HX, ZQC and ZQY: Writing and revision of the manuscript. All authors read and approved the final manuscript.

\section{Ethics approval and consent to participate}

This article does not contain any studies with human participants or animals performed by any of the authors.

\section{Competing interests}

The authors declare that they have no competing interests.

\section{Publisher's Note}

Springer Nature remains neutral with regard to jurisdictional claims in published maps and institutional affiliations.

\section{Received: 9 January 2018 Accepted: 23 April 2018}

Published online: 03 May 2018

\section{References}

1. Nickel JC, Saad F. The American urological association 2003 guideline on management of benign prostatic hyperplasia: a Canadian opinion. Can J Urol. 2004;11:2186-93.

2. Welch G, Weinger K, Barry MJ. Quality-of-life impact of lower urinary tract symptom severity: results from the health professionals follow-up study. Urology. 2002;59:245-50

3. Wei JT, Calhoun E, Jacobsen SJ. Urologic diseases in america project: benign prostatic hyperplasia. J Urol. 2008;179:S75-80.

4. Colella J, Kochis E, Galli B, et al. Urolithiasis/nephrolithiasis: what's it al about? Urol Nurs. 2005:25:427-48. 75, 49

5. Hollingsworth JM, Rogers MA, Kaufman SR, et al. Medical therapy to facilitate urinary stone passage: a meta-analysis. Lancet (London, England). 2006:368:1171-9.
6. Jayant K, Agrawal R, Agrawal S. Tamsulosin versus tamsulosin plus tadalafi as medical expulsive therapy for lower ureteric stones: a randomized controlled trial. Int J Urol. 2014;21:1012-5.

7. Stohrer M, Blok B, Castro-Diaz D, et al. EAU guidelines on neurogenic lower urinary tract dysfunction. Eur Urol. 2009;56:81-8.

8. Lepor H. Medical treatment of benign prostatic hyperplasia. Rev Urol. 2011; 13:20-33.

9. Speakman MJ, Kirby RS, Joyce A, et al. Guideline for the primary care management of male lower urinary tract symptoms. BJU Int. 2004;93:985-90.

10. Rosen RC, Giuliano F, Carson CC. Sexual dysfunction and lower urinary tract symptoms (LUTS) associated with benign prostatic hyperplasia (BPH). Eur Urol. 2005;47:824-37.

11. Porpiglia F, Vaccino D, Billia $M$, et al. Corticosteroids and tamsulosin in the medical expulsive therapy for symptomatic distal ureter stones: single drug or association? Eur Urol. 2006;50:339-44.

12. Wyllie MG. Monotherapy for comorbid erectile dysfunction and lower urinary tract symptoms: phosphodiesterase inhibitor or alpha-adrenoceptor antagonist? BJU Int. 2012;109:965-6

13. Kumar S, Jayant K, Agrawal MM, et al. Role of tamsulosin, tadalafil, and silodosin as the medical expulsive therapy in lower ureteric stone: a randomized trial (a pilot study). Urology. 2015:85:59-63.

14. Gratzke C, Uckert S, Kedia G, et al. In vitro effects of PDE5 inhibitors sildenafil, vardenafil and tadalafil on isolated human ureteral smooth muscle: a basic research approach. Urol Res. 2007;35:49-54.

15. Capitanio U, Salonia A, Briganti A, et al. Silodosin in the management of lower urinary tract symptoms as a result of benign prostatic hyperplasia: who are the best candidates. Int J Clin Pract. 2013;67:544-51.

16. Oelke M, Bachmann A, Descazeaud A, et al. EAU guidelines on the treatment and follow-up of non-neurogenic male lower urinary tract symptoms including benign prostatic obstruction. Eur Urol. 2013;64:118-40.

17. Oelke M, Giuliano F, Mirone V, et al. Monotherapy with tadalafil or tamsulosin similarly improved lower urinary tract symptoms suggestive of benign prostatic hyperplasia in an international, randomised, parallel, placebo-controlled clinical trial. Eur Urol. 2012;61:917-25.

18. Gacci M, Corona G, Salvi M, et al. A systematic review and meta-analysis on the use of phosphodiesterase 5 inhibitors alone or in combination with alpha-blockers for lower urinary tract symptoms due to benign prostatic hyperplasia. Eur Urol. 2012;61:994-1003.

19. Wang $X H$, Wang $X$, Shi MJ, et al. Systematic review and meta-analysis on phosphodiesterase 5 inhibitors and alpha-adrenoceptor antagonists used alone or combined for treatment of LUTS due to BPH. Asian J Androl. 2015; 17:1022-32.

20. International Prospective Register of Systematic Reviews [http://www.crd. york.ac.uk/prospero]. Accessed 16 Mar 2017.

21. Moher D, Liberati A, Tetzlaff J, et al. Preferred reporting items for systematic reviews and meta-analyses: the PRISMA statement. Ann Int Med. 2009;151: 264-9. w64

22. Sterne JA, Juni P, Schulz KF, et al. Statistical methods for assessing the influence of study characteristics on treatment effects in 'metaepidemiological' research. Stat Med. 2002;21:1513-24.

23. DerSimonian R. Meta-analysis in the design and monitoring of clinical trials. Stat Med. 1996;15:1237-48. discussion 49-52

24. Blunch NJ. Statistical analysis of data from clinical and retrospective studies. Ugeskr Laeger. 1976;138:401-7.

25. Kc HB, Shrestha A, Acharya GB, et al. Tamsulosin versus tadalafil as a medica expulsive therapy for distal ureteral stones: a prospective randomized study. Investig Clin Urol. 2016:57:351-6.

26. Puvvada S, Mylarappa P, Aggarwal K, et al. Comparative efficacy of tadalafil versus tamsulosin as the medical expulsive therapy in lower ureteric stone: a prospective randomized trial. Cent European J Urol. 2016;69:178-82

27. Kumar S, Jayant K, Agrawal S, et al. Comparative efficacy of tamsulosin versus tamsulosin with tadalafil in combination with prednisolone for the medical expulsive therapy of lower ureteric stones: a randomized trial. Korean J Urol. 2014;55:196-200

28. Regadas RP, Reges R, Cerqueira JB, et al. Urodynamic effects of the combination of tamsulosin and daily tadalafil in men with lower urinary tract symptoms secondary to benign prostatic hyperplasia: a randomized, placebo-controlled clinical trial. Int Urol Nephrol. 2013;45:39-43.

29. Kim SC, Park JK, Kim SW et al. Tadalafil administered once daily for treatment of lower urinary tract symptoms in Korean men with benign 
prostatic hyperplasia: results from a placebo-controlled pilot study using Tamsulosin as an active control. Low Urin Tract Symptoms. 2011;3:86-93.

30. Bechara A, Romano S, Casabe A, et al. Comparative efficacy assessment of tamsulosin vs. tamsulosin plus tadalafil in the treatment of LUTS/BPH. Pilot study. J Sex Med. 2008:5:2170-8.

31. Singh DV, Mete UK, Mandal AK, et al. A comparative randomized prospective study to evaluate efficacy and safety of combination of tamsulosin and tadalafil vs. tamsulosin or tadalafil alone in patients with lower urinary tract symptoms due to benign prostatic hyperplasia. J Sex Med. 2014;11:187-96.

32. Kaplan SA, Gonzalez RR, Te AE. Combination of alfuzosin and sildenafil is superior to monotherapy in treating lower urinary tract symptoms and erectile dysfunction. Eur Urol. 2007;51:1717-23.

33. Abolyosr A, Elsagheer GA, Abdel-Kader MS, et al. Evaluation of the effect of sildenafil and/or doxazosin on benign prostatic hyperplasia-related lower urinary tract symptoms and erectile dysfunction. Urol Ann. 2013;5:237-40.

34. Jin Z, Zhang ZC, Liu JH, et al. An open, comparative, multicentre clinical study of combined oral therapy with sildenafil and doxazosin GITS for treating Chinese patients with erectile dysfunction and lower urinary tract symptoms secondary to benign prostatic hyperplasia. Asian J Androl. 2011;13:630-5.

35. Tuncel A, Nalcacioglu V, Ener K, et al. Sildenafil citrate and tamsulosin combination is not superior to monotherapy in treating lower urinary tract symptoms and erectile dysfunction. World J Urol. 2010;28:17-22.

36. Liguori G, Trombetta C, De Giorgi G, et al. Efficacy and safety of combined oral therapy with tadalafil and alfuzosin: an integrated approach to the management of patients with lower urinary tract symptoms and erectile dysfunction. Preliminary report. J Sex Med. 2009;6:544-52.

37. Ng CF, Wong A, Cheng CW, et al. Effect of vardenafil on blood pressure profile of patients with erectile dysfunction concomitantly treated with doxazosin gastrointestinal therapeutic system for benign prostatic hyperplasia. J Urol. 2008;180:1042-6.

38. Gacci M, Vittori G, Tosi N, et al. A randomized, placebo-controlled study to assess safety and efficacy of vardenafil $10 \mathrm{mg}$ and tamsulosin $0.4 \mathrm{mg}$ vs. tamsulosin $0.4 \mathrm{mg}$ alone in the treatment of lower urinary tract symptoms secondary to benign prostatic hyperplasia. J Sex Med. 2012;9:1624-33.

39. Kumar S, Kondareddy C, Ganesamoni R, et al. Randomized controlled trial to assess the efficacy of the combination therapy of Alfuzosin and Tadalafil in patients with lower urinary tract symptoms due to benign prostatic hyperplasia. Low Urin Tract Symptoms. 2014;6:35-40.

40. Mehrazmay A, Karambakhsh A, Salesi M. Reporting quality assessment of randomized controlled trials published in nephrology urology monthly journal. Nephrourol Mon. 2015;7:e28752.

41. Yuan JQ, Yang ZY, Mao C. Re: Mauro Gacci, Giovanni Corona, Matteo Salvi, et al. a systematic review and meta-analysis on the use of phosphodiesterase 5 inhibitors alone or in combination with alpha-blockers for lower urinary tract symptoms due to benign prostatic hyperplasia. Eur Urol. 2012;61:994-1003. European urology. 2012; 62:e35; author reply e6-8

42. Laydner HK, Oliveira P, Oliveira CR, et al. Phosphodiesterase 5 inhibitors for lower urinary tract symptoms secondary to benign prostatic hyperplasia: a systematic review. BJU Int. 2011:107:1104-9.

43. Liu L, Zheng S, Han P, et al. Phosphodiesterase-5 inhibitors for lower urinary tract symptoms secondary to benign prostatic hyperplasia: a systematic review and meta-analysis. Urology. 2011;77:123-9.

44. Fibbi B, Morelli A, Vignozzi L, et al. Characterization of phosphodiesterase type 5 expression and functional activity in the human male lower urinary tract. J Sex Med. 2010;7:59-69.

45. Tinel $H$, Stelte-Ludwig B, Hutter J, et al. Pre-clinical evidence for the use of phosphodiesterase- 5 inhibitors for treating benign prostatic hyperplasia and lower urinary tract symptoms. BJU Int. 2006;98:1259-63.

46. Dmochowski R, Roehrborn C, Klise $S$, et al. Urodynamic effects of once daily tadalafil in men with lower urinary tract symptoms secondary to clinical benign prostatic hyperplasia: a randomized, placebo controlled 12-week clinical trial. J Urol. 2010;183:1092-7.

47. Braun M, Wassmer G, Klotz T, et al. Epidemiology of erectile dysfunction: results of the 'Cologne male Survey'. Int J Impot Res. 2000;12:305-11.

48. Gacci M, Bartoletti R, Figlioli S, et al. Urinary symptoms, quality of life and sexual function in patients with benign prostatic hypertrophy before and after prostatectomy: a prospective study. BJU Int. 2003;91:196-200.
49. Rosen R, Altwein J, Boyle $\mathrm{P}$, et al. Lower urinary tract symptoms and male sexual dysfunction: the multinational survey of the aging male (MSAM-7). Eur Urol. 2003:44:637-49.

50. Vallancien $\mathrm{G}$, Emberton M, Harving $\mathrm{N}$, et al. Sexual dysfunction in 1,274 European men suffering from lower urinary tract symptoms. J Urol. 2003; 169:2257-61.

51. Uckert S, Oelke M, Stief CG, et al. Immunohistochemical distribution of CAMP- and CGMP-phosphodiesterase (PDE) isoenzymes in the human prostate. Eur Urol. 2006:49:740-5.

52. Kedia GT, Oelke M, Sonnenberg JE, et al. Phosphodiesterase isoenzymes in the human urethra: a molecular biology and functional study. Eur J Pharmacol. 2014;741:330-5.

53. Sairam K, Kulinskaya E, McNicholas TA, et al. Sildenafil influences lower urinary tract symptoms. BJU Int. 2002;90:836-9.

54. Vignozzi L, Gacci M, Cellai I, et al. PDE5 inhibitors blunt inflammation in human BPH: a potential mechanism of action for PDE5 inhibitors in LUTS. Prostate. 2013;73:1391-402.

55. Fusco F, di Villa Bianca R, Mitidieri E, et al. Sildenafil effect on the human bladder involves the L-cysteine/hydrogen sulfide pathway: a novel mechanism of action of phosphodiesterase type 5 inhibitors. Eur Urol. 2012; 62:1174-80

56. Cohen PG. Intra-abdominal pressure, LUTS, and tadalafil. Re: Andersson K-E, et al. tadalafil for the treatment of lower urinary tract symptoms secondary to benign prostatic hyperplasia: pathophysiology and mechanism(s) of action. Neurourol urodyn 2011;30:292-301. Neurourol Urodyn. 2012;31:706.

57. Giuliano F, Uckert S, Maggi M, et al. The mechanism of action of phosphodiesterase type 5 inhibitors in the treatment of lower urinary tract symptoms related to benign prostatic hyperplasia. Eur Urol. 2013;63:506-16.

58. Morelli A, Sarchielli E, Comeglio P, et al. Phosphodiesterase type 5 expression in human and rat lower urinary tract tissues and the effect of tadalafil on prostate gland oxygenation in spontaneously hypertensive rats. J Sex Med. 2011;8:2746-60.

\section{Ready to submit your research? Choose BMC and benefit from:}

- fast, convenient online submission

- thorough peer review by experienced researchers in your field

- rapid publication on acceptance

- support for research data, including large and complex data types

- gold Open Access which fosters wider collaboration and increased citations

- maximum visibility for your research: over $100 \mathrm{M}$ website views per year

At BMC, research is always in progress.

Learn more biomedcentral.com/submissions 